
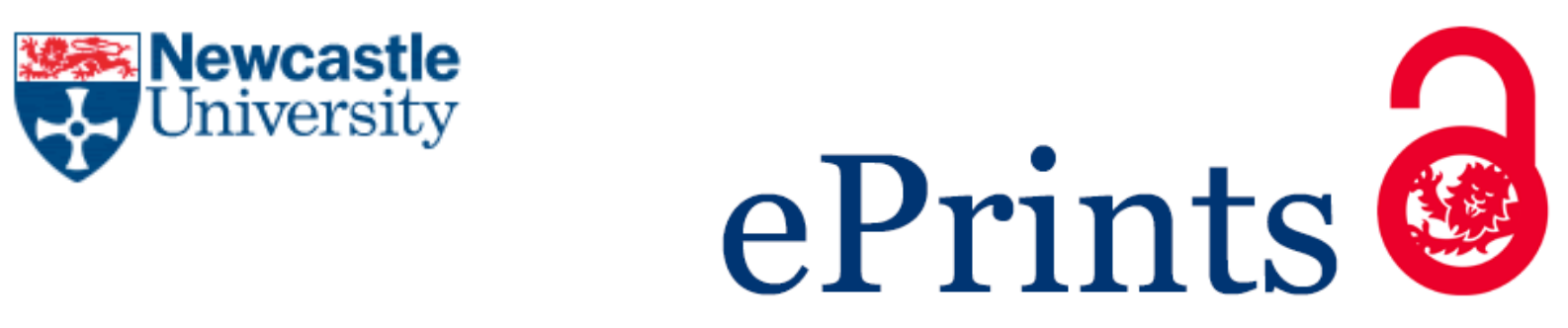

Siemens D.

Writing the History of the SA at the International Military Tribunal: Legal Strategies and Long-term Historiographical Consequences. Journal of Modern European History 2016, 14(4), 548-567.

\title{
Copyright:
}

This is the author's accepted manuscript of an article that was published in its final definitive form by C.H.Beck, 2016.

DOI link to article:

https://doi.org/10.17104/1611-8944-2016-4-548

Date deposited:

$15 / 02 / 2018$

Embargo release date:

03 October 2017 


\section{Daniel Siemens}

\section{Writing the History of the SA at the International Military}

Tribunal: Legal Strategies and Long-term Historiographical

\section{Consequences}

After the armistice of 8 May 1945, civilians only slowly returned to Berlin, now a city of ruins, hunger and disease. From more than four million inhabitants in the early 1920s, the number of "Berliners" had decreased to fewer than three million, many of them physically and morally wounded. One of the early returnees to the capital was the writer Rudolf Ditzen, better known under his pseudonym Hans Fallada. His novel Kleiner Mann, was nun? (Little Man, What Now?), a touching story about a lower middle-class couple suffering from the years of depression that was first published in 1932, had made him famous shortly before the Nazis came to power. Unlike many of the Jewish and left-liberal writers, Fallada had been able to publish novels that sold relatively well in the first years of the "Third Reich". He had survived the war years in a kind of "inner exile" in Northern Germany, standing aloof from the centre of political power. However, in 1945, Fallada returned to Berlin and, in a kind of frenzy, wrote 
down his last novel within a few weeks in the fall of 1946. Shortly afterwards, he died, aged $53 . .^{1}$

This last novel, Jeder stirbt für sich allein (English: Alone in Berlin), re-discovered in recent years and nowadays read by an international audience, provides a literary panorama of German society between 1941 and the end of the Third Reich. Engagingly written and full of anger and hate, but also a testimony of Fallada's profound sadness in light of the omnipresent destruction and despair, it is a book that contains not only a literary truth, but is also a first-rank source for a history of mentalities of the immediate post-war period. It is yet by and large free of the distortions that would soon penetrate most accounts of life under National Socialism in the following decades. ${ }^{2}$ With regard to the importance of the SA during the war years, this book is

1 see A. Giesecke, "Nachwort", in: H. Fallada, Jeder stirbt für sich allein, Berlin 2013, 687-699, and the contributions in C. Gansel / W. Liersch (eds.), Zeit vergessen, Zeit erinnern: Hans Fallada und das kulturelle Gedächtnis, Göttingen 2008 .

2 This holds true even if one takes into account that Fallada had been commissioned by Johannes R. Becher, the president of the "Kulturbund zur demokratischen Erneuerung Deutschlands" and, since 1954, the first culture secretary of the GDR to write such a book. 
revealing as - in passing - the reader can't escape the notion to what important degree the Party uniforms of SA, SS and HJ dominated the streets of the German capital. Stormtroopers appear far from being mere decors of the Nazi state; instead, they are portrayed as powerful and dangerous arch-Nazis that are able to intimidate "ordinary" German workers in a factory meeting, have the power to send people into concentration camps at their convenience and can even put the political police under serious pressure. Later historians have confirmed this view, often citing the intensified persecution of Jews over the year 1938 that culminated in the infamous pogrom of 9 November as prime example. ${ }^{3}$ Mathilde Jamin rightly emphasised that, irrespective of the degradation of the SA because of the "Night of the Long Knives" on 30 June 1934, uniformed stormtroopers remained a well-known signal of danger in the

3 From the considerable amount of studies, see recently A. Steinweis, Kristallnacht 1938, London 2009; M. Wildt, Volksgemeinschaft als Selbstermächtigung: Gewalt gegen Juden in der deutschen Provinz 1919 bis 1939, Hamburg 2007, 301-351; K. Wünschmann, Before Auschwitz: Jewish Prisoners in the Prewar Concentration Camps, Cambridge, MA 2015, 168-210; Chr. Faludi, Die "Juni-Aktion" 1938: Eine Dokumentation zur Radikalisierung der Judenverfolgung, Frankfurt a. M., 2013; Chr. Kreutzmüller / B. Weigel, Kristallnacht? Bilder der Novemberpogrome 1938 in Berlin, Berlin 2013. 
following years. 4 In his novel, Fallada used this "signal effect" of the Nazi uniform and coupled it with the back-then popular strategy of excuse, summarily referring to "Aryan" and "non-Aryan" Germans as the first victims of the Third Reich. In his portrait of Berlin in the early 1940s, most Germans and German Jews in particular lived in a form of prison, kept under guard, bereaved and tortured by Nazi Party officials, SA and S. 5

4 M. Jamin, "Zur Rolle der SA im nationalsozialistischen Herrschaftssystem", in: G. Hirschfeld / L. Kettenacker (eds.), Der Führerstaat: Mythos und Realität. Studien zur Struktur und Politik des Dritten Reiches, Stuttgart 1981, 329-360, 357.

5 In this respect, Fallada's interpretation is typical for the tendency of Germans in the post-war period to initially concentrate on one's own suffering, emphasising the character of the Nazi state as "terror regime", the German loss of lives during the war and the expulsions of ethnic Germans from Eastern Europe between 1944 and 1948. In return, the fate of the Sinti and Roma, of the non-German Jewry, of the up to eight million forced labourers and of the German murder of millions of civilians throughout Europe was largely ignored, at least until the 1960s. For a general assessment of this aspect of post-war (West) Germany see N. Frei, Adenauer's Germany and the Nazi Past: The Politics of Amnesty and Integration, New York 2002. 


\section{Entangled Narratives of Power and Decline}

In the years after Fallada's death, many Germans initially shared his view that the brownshirts had been a kind of ugly face of National Socialism - partly echoing the 1934 accusations against the former SA leadership under Ernst Röhm. ${ }^{6}$ In the summer of 1934, Hitler had presented the "moral failures" of Röhm and his entourage as the tip of the iceberg of an allegedly substantially rotten and corrupted mass

6 For public reactions to the "Night of the Long Knives" see M. Jamin, "Das Ende der 'Machtergreifung': Der 30. Juni 1934 und seine Wahrnehmung in der Bevölkerung", in: W. Michala (ed.), Die nationalsozialistische Machtergreifung, Paderborn 1984, 207-219; F. Bösch, Das konservative Milieu: Vereinskultur und lokale Sammlungspolitik in ost-und westdeutschen Regionen (1900-1960), Göttingen 2002, 138; R. Bessel, Political Violence and the Rise of Nazism: The Storm Troopers in Eastern Germany 1925-1934, New Haven, CT 1984, 143; E. Hancock, Ernst Röhm: Hitler's SA Chief of Staff, Basingstoke 2008, 164-166; P. Longerich, Geschichte der SA, Munich 2003, 220; Report from Jacob W. S. Wuest, U.S. Military Attaché in Berlin, to the Department of State from 2.7.1934, in: Archive "Der Spiegel" (Hausdokumentation), Personal Papers of Heinz Höhne, No. 121; Sopade, Deutschland-Berichte, vol. 1 $(1934), 1980,191-195$ 
organisation that had threatened the state. He thereby elevated his political murder into an act of necessary moral cleansing and liberation. ${ }^{7}$ As the Sopade-Berichte, reports from all parts of the Reich collected by the Social democratic Party in exile, make clear, such reasoning caught on. The reports repeatedly emphasise the $\mathrm{SA}^{\prime} \mathrm{S}$ decline and its "lack of purpose", in particular in the years 1935 and 1936, before they then start to acknowledge that the discipline and morale of the stormtroopers improved again. Throughout the early years of the Third Reich, however, most of these reports distinguished between the (temporary) decline of the SA as an organisation and the persistent power of the individual Nazi in uniform. 8

Such ambivalences were quickly forgotten once the Third Reich had vanished. By the early 1950s, the SA stood for the features that had made National Socialism such an ostracised political ideology: above all its brutal violence and a complete lack of compassion for those deemed outsiders of the

7 See Hitler's infamous Reichstag speech on 13.7.1934, as quoted in M. Domarus (ed.), Hitler: Reden und Proklamationen. Vol. 1/1: Triumph, Munich 1965, 409-424.

8 Sopade, Deutschland-Berichte, vol. 1 (1934), 249-253, 302342, vol. 2 (1935), 607-614,946-948; vol. 3 (1936), 851-862. 
Volksgemeinschaft ("people's community"). 9 A particularly damnatory assessment came from the former "National Bolshevik" Ernst Niekisch, whom the Nazis had imprisoned in 1937. In his book Das Reich der niederen Dämonen (Reich of the Menial Demons), published in the Federal Republic of Germany in 1953, Niekisch described the SA as "a counter-elite" that supposedly "attracted all those characters who were rotten and frail from within. In the SA, all criminal inclinations were let loose. The SA barracks were dens of vice; there were work-shy individuals, drunkards, losers (Lebensbankrotteure), homosexuals, ruffians and killers who hatched their sinister attacks by which Germany should be 'awoken'".10 Contrary to what Niekisch and other Nazi critics intended, such public scolding now contributed to the fact that the

9 For the intense debate about the nature of the "people's community" and the applicability of this term for historical analysis, see the contributions in M. Steber / B. Gotto (eds.), Visions of Community in Nazi Germany: Social Engineering \& Private Lives, Oxford 2014, as well as J. Steuwer's excellent review article: "Was meint und nützt das Sprechen von der 'Volksgemeinschaft'? Neuere Literatur zur Gesellschaftsgeschichte des Nationalsozialismus", in: Archiv für Sozialgeschichte 53 (2013), 487-534.

10 E. Niekisch, Das Reich der niederen Dämonen, Hamburg 1953, 115. 
former Janus-faced image of the SA - established in the 1930s, as we have seen - quickly lost complexity. In fact, the organisational limits of the SA more and more came to serve as a most welcome opportunity to belittle one's former commitment to the Nazi cause. Former stormtroopers now claimed that, because the original SA from the pre-1934 period had been successfully "purified", the alleged unimportance of this organisation in the remaining years of the Third Reich would also prove the harmlessness of its former members. They even began to publicly claim honourable motives. Such views were advanced by Ernst Salomon most influential novel Der Fragebogen (The Questionnaire), a bestseller on the West German book market that sold 200.000 copies in the first year after its publication in 1951 alone. ${ }^{11}$ Towards the end of his novel, Salomon gives a very sympathetic portray of Hanns E. Ludin, the long-time leader of the SA in Württemberg who was appointed German envoy in Slovakia in 1941. According to Salomon, Ludin, who was executed in Bratislava in December 1947, had been an impeccable German patriot and idealist, whereas "in the eyes of the majority of the population" the SA had been transformed into the "most harmless" of all Nazi

11 For a detailed analysis of the novel's reception see A. Parkinson, An Emotional State: The Politics of Emotion in Postwar West German Culture, Ann Arbor, MI 2015, 103-111. 
organisations after June 1934. ${ }^{12}$ This distinction between individual merit and organisational failure is characteristic for Salomon's entire novel. He belittled and even ridiculed the deadly power of the Nazi state and its organisations and contrasted this with individual examples of German men and women who had allegedly stayed morally clean or had even acted heroically. This narrative was a more than welcome invitation for many West Germans in the 1950 s to paint their own biographies in similar colours. Early academic scholarship on the stormtroopers did little to question such exculpatory assessments. The early expert opinions on the SA from historian Hans Buchheim, written between 1955 and 1957, deal with topics that back then were of use for the German administrations when they had to decide on questions of entitlements to maintenance or on retirement benefits of former SA members, but they had little to say on central historiographical questions about the character of the SA and its political clout after $1933 .{ }^{13}$ A few years later,

12 E. Salomon, Der Fragebogen, Reinbek near Hamburg, ${ }^{19} 2011$ $[1951], 637-638$.

13 See H. Buchheim's expert opinions "SA-Anwärter", "Die SAWehrmannschaften" and "Die Eingliederung des Stahlhelm in die SA", all in: Institut für Zeitgeschichte (ed.), Gutachten des Instituts für Zeitgeschichte, Munich 1958, 334-343, 370-377. For an analysis of the importance of the Institut für 
the four expert opinions written for the Frankfurt Auschwitz trial in 1964 and intended to provide the judges with a trustworthy overview of the political and historical developments during the Nazi's rise to power and in the Third Reich were published in 1967 as a book with the telling title Anatomie des SS-Staates. ${ }^{14}$ In this book, the SA is only mentioned in passing, and only in as much as its role in the terror prior to the Nazi takeover of power and then in the establishment of the Third Reich in 1933/1934 was concerned.15

Zeitgeschichte for the early historiography on the SA, in particular with regard to the books written by the academically trained historian and former SA leader Heinrich Bennecke, see my forthcoming book on the SA. For the general problem of a close collaboration between the Institute's way of writing contemporary history in its early years, at times relying on narratives and "factual" information provided by former Nazi luminaries, see N. Berg, Der Holocaust und die westdeutschen Historiker: Erforschung und Erinnerung, Göttingen 2003 .

14 This title certainly alluded to E. Kogon's eyeopening book Der SS-Staat: Das System der deutschen Konzentrationslager, Munich 1946.

15 See above all the expert opinions of Hans Buchheim and Martin Broszat in: H. Buchheim et al.(eds.), Anatomie des SSStaates, Munich 1999 [1967], 218-225, 336-351. 
The actual book of reference on the history of the SA in German, Peter Longerich's Die braunen Bataillone: Geschichte der SA, first published in 1989 and re-edited with a new afterword in 2003, still reflects this tendency. Whereas Longerich analysed the emergence of the SA and its rapid growth during since the late 1920s in detail, he reserved only one concluding chapter to the history of the stormtroopers between 1934 and 1945, the eleven years of consolidated Nazi rule. ${ }^{16}$ Infrequent interventions, first by the historian Bruce Campbell and most recently by Yves Müller and myself, have challenged the paradigm of the allegedly "unimportant" SA

16 P. Longerich, Die braunen Bataillone. Geschichte der SA, Munich 1989, 220-245. Similar to Longerich, nearly all studies that focus on the SA concentrate on its history prior to the "Röhm purge". From the most recent literature see A. Wackerfuss, Stormtrooper Families: Homosexuality and Community in the Early Nazi Movement, New York 2015; S. Hördler (ed.), SA-Terror als Herrschaftssicherung: "Köpenicker Blutwoche" und öffentliche Gewalt im Nationalsozialismus, Berlin 2013; Y. Müller / R. Zilkenat (eds.), Bürgerkriegsarmee: Forschungen zur nationalsozialistischen Sturmabteilung (SA), Frankfurt a. M. 2013; S. Reichardt, Faschistische Kampfbünde: Gewalt und Gemeinschaft im italienischen Squadrismus und in der deutschen SA, Köln 22009 . 
after its "decapitation" in the summer of 1934, but so far they did not achieve a general change of perspective. ${ }^{17}$

\section{Shaping History: The International Military Tribunal (IMT) and its Accusations}

In what follows, I will take the IMT's proceedings against the SA in Nuremberg as an exemplary test case for analysing the correlation between legal practices and historiography. More precisely, I am interested in the narrative that was generated in the interaction of these two practises. Even if one does not agree with Robert Kempner's early emphatic assessment that the IMT was "the greatest history seminar ever held", historical research over the last decades has confirmed that the trial "embraced a didactic purpose", aiming at providing a moral lesson that would stand independent of the sentencing of

17 B. Campbell, "The SA after the Röhm Purge", in: Journal of Contemporary History 28 (1993) 4, 659-674; Y. Müller, "Wilhelm Schepmann - der letzte SA-Stabschef und die Rolle der SA im Zweiten Weltkrieg", in: Zeitschrift für Geschichtswissenschaft 63 (2015) 6, 513-532; D. Siemens, "Dem SA-Mann auf der Spur: Nationalsozialistische Erinnerungspolitik im Berlin der 1930er-Jahre", in: Hördler (ed.), SA-Terror als Herrschaftssicherung, 147-163. 
individual defendants. ${ }^{18}$ The Nazi organisations that stood trial were therefore of particular relevance, as the outcome of the IMT potentially impacted heavily on the lives of the former members of these organisations comprising of several million men in the case of the SA alone. ${ }^{19}$ As the IMT was the first legal authority that established an interpretation that distinguished sharply between a pre-1934 SA and the later years, it set the path not only for subsequent criminal proceedings, but also for the analysis of later historians. In this respect, the Nuremberg judges indeed wrote history - with lasting effects.

18 L. Douglas, "The Didactic Trial: Filtering History and Memory into the Courtroom", in: D. Bankier / D. Michman (eds.), Holocaust and Justice: Representation \& Historiography of the Holocaust in Post-War Trials, Jerusalem, New York 2010, $11-22,11-12$.

19 On the legal and political challenges of a criminal trial against mass organisations see E. Conze, "'Verbrecherische Organisation': Genese, Anwendung und Reichweite einer Rechtsfigur", in: J. Hürter / M. Mayer (ed.), Das Auswärtige Amt in der NS-Diktatur, Munich 2014, 219-238; G. Rauschenbach, Der Nürnberger Prozeß gegen die Organisationen. Grundlagen, Probleme, Auswirkungen auf die Mitglieder und ihre strafrechtlichen Ergebnisse, Bonn 1954, 15-17, 40-67, 89-90 (on the verdict against the SA). 
For a detailed analysis of this phenomenon, some background information on the IMT and its proceedings are necessary: Alongside leading politicians, military commanders and business leaders of the Third Reich like Hermann Göring, Rudolf Heß, Karl Dönitz and Hjalmar Schacht - to name just some of the 24 defendants -, some of the most important repressive and terror organisations of the Nazi state like the SS, the Gestapo and the SA also stood trial. 20 They were to be declared "criminal organisations" if they had provided the framework in which their members had committed "crimes against peace", were responsible for "war crimes" or had participated in "crimes against humanity". According to article six of the charter of the IMT from 8 August 1945, crimes against peace were defined as the "planning, preparation, initiation or waging of a war of aggression, or a war in violation of international treaties, agreements or assurances, or

20 The research literature on the post war trials fills a bibliography on its own. For recent historiographical overviews see K. C. Priemel, "Consigning Justice to History: Transitional Trials after the Second World War", in: The Historical Journal 56 (2013) 2, 553-581; idem / A. Stiller, "Introduction: Nuremberg's Narratives. Revising the Legacy of the 'Subsequent Trials'", in: idem (eds.), Reassessing the Nuremberg Military Tribunals: Transitional Justice, Trial Narratives, and Historiography, New York 2012, 1-21. 
participation in a common plan or conspiracy for the accomplishment of any of the foregoing". War crimes, the same article stated, included "murder, ill-treatment or deportation to slave labor or for any other purpose of civilian population of or in occupied territory, murder or ill-treatment of prisoners of war or persons on the seas, killing of hostages, plunder of public or private property, wanton destruction of cities, towns or villages, or devastation not justified by military necessity". This was not an exclusive list, but meant as an enumeration that set the tone for the proceedings to follow. Finally, "crimes against humanity", a new legal category applied for the first time by the IMT and highly contested with regard to its technical applicability, incorporated murder, the extermination, enslavement or deportation as well as other inhumane acts committed against any civilian population, and this - another novelty regardless whether or not these acts were committed in violation of the "domestic law of the country where perpetrated". 21

21 Article 6 of the Agreement for the Prosecution and Punishment of the Major War Criminals of the European Axis, and Charter of the International Military Tribunal, London, 8.8.1945 (http://www.icrc.org/ihl.nsf/FULL/350, last accessed 13.7.2015). On the legal aspects of the category "crimes against humanity" see also the detailed analysis of D. M. 
A possible declaration of the SA as a "criminal organisation" would have had direct consequences for the judicial proceedings against Nazi criminals in the years to come. In the case of a positive verdict from the IMT, membership in the SA alone would have been a sufficient ground for legal punishment in post-war Germany, without the courts having to prove the individual guilt of a particular defendant. Understandingly, such a verdict would have been a worst-case scenario for millions of former SA men. A considerable number of them supported the Nuremberg defence team for the SA by writing affidavits that at best acknowledged that some individual SA men had not always behaved properly, but exempted the SA as an organisation from all charges. No less than 10.000 people had provided affidavits on behalf of the SA, the court informed the public on 30 september 1946, the day the verdict was pronounced. 22

Segesser, "Der Tatbestand Verbrechen gegen die Menschlichkeit", in: K. C. Priemel / A. Stiller (eds.), NMT: Die Nürnberger Militärtribunale zwischen Geschichte, Gerechtigkeit und Rechtsschöpfung, Hamburg 2013, 586-604; on the origins of the legal concept of "conspiracy", advanced in particular in the United States since 1943, see Conze, "Verbrecherische Organisation", 221-225. 22 Statement of the President of the IMT, Geoffrey Lawrence, on 30.9.1946, in: Secretariat of the Tribunal under the 
Characteristic for the usually apologetic tone of these documents is a detailed memorandum by SA-Obergruppenführer Max Jüttner, written while in American custody in Internment Camp 75 in Kornwestheim near Stuttgart in January 1946.23 Jüttner was one of the two surviving SA leaders who had temporarily led the SA between 2 May and 8 August 1943 (to be followed by Wilhelm Schepmann). According to his own words, he read about the Nuremberg trial in the newspapers available at the camp and, "as the only SA representative within reach", immediately contacted the IMT in October 1945. As the court did not pay much attention to his initial correspondence, he set out to write a justification of the SA (and himself), encouraged by defence lawyer Robert Servatius, in January 1946.24 Jüttner's

jurisdiction of the Allied Control Authority for Germany (ed.), Trial of the Major War Criminals before the International Military Tribunal, Nuremberg, 14 November 1945 1 October 1946 (The Blue Series), Nuremberg 1947/48, vol. 22, 413.

23 M. Jüttner, "Führung, Aufgaben und Tätigkeit der SA und Nürnberger Prozess", in: Institut für Zeitgeschichte, München ZS $251 / 1$.

24 Ibid., 3-4. At the IMT, Dr. Robert Servatius defended the Thuringian Gauleiter Fritz Sauckel and the NSDAP leadership corps (Priemel / Stiller, NMT, 761-762). He later also served as defence lawyer of Adolf Eichmann in Jerusalem. 
lengthy vindication of nearly one hundred pages often resembles a caricature, in particular with regard to the $\mathrm{SA}^{\prime} \mathrm{S}$ attitude towards Jews and political enemies: According to Jüttner, neither the long-time SA Chief of Staff Viktor Lutze, in charge of the SA between 1934 and 1943, nor he himself had ever ordered the discrimination or persecution of Jews. Only from the Allies had he learned about possible cruelty and torture in the concentration camps. Every reasonable man, who lets justice prevail, will give the SA credit to its honourable motives, Jüttner wrote. 25

\section{A Conspiracy for War: The Arguments of the Prosecution}

The oral proceedings against the SA began in the afternoon of 18 December 1945, the 22nd day of the trial. As it was common practice, the prosecution as well as the defence relied heavily on a large number of documents that were serially numbered. In fact, the hearings often resulted in clashes over the applicability of certain key documents, next to the hearing of witnesses (Jüttner among them). The main prosecutor for the SA was the American jurist, Col. Robert G. Storey. In Nuremberg, he acted as executive trial counsel on the request of the chief prosecutor Robert H. Jackson: "Together with nine

25 Jüttner, "Führung", 11-12, 22. 
colleagues Storey coordinated the evidence and decided on the sequence of the proceeding."26

Storey began his accusation by defining the aim and scope of the SA, apparently not without difficulties. According to the prosecutor, the SA

[...] was an agency adapted to many designs and purposes, and its role in the conspiracy changed from time to time always corresponding with the progression of the conspiracy through its various phases towards the final objective: abrogation of the Versailles Treaty and acquisition of the territory of other peoples and nations. If we might consider this conspiracy as a pattern, with its various parts fitting together like the pieces of a jigsaw puzzle, we would find that the piece representing the SA constituted a link in the pattern vitally necessary to the presentation and development of the entire picture. ${ }^{27}$

26 D. Gaitner, "Robert Gerhard Storey, A Prosecution Counsel at Nuremberg Trials", in: The New York Times, 18.1.1981, http: //www. nytimes.com/1981/01/18/obituaries/robert-gerardstorey-a-prosecution-counsel-at-nuremberg-trials.html [last accessed 12.4.2016].

27 Statement of Robert G. Storey on 18.12.1945, in: Trial of the Major War Criminals, vol. 4, 124. 
"Conspiracy", as used here, meant the Nazis" attempt to overthrow the democratic state of Weimar and to replace it with a Fascist dictatorship that would strive to transform itself into a European empire by attacking and occupying other countries. As the most distinct feature of the SA, Storey identified that all members shared "a fanatical adherence to the philosophies and ideologies conceived by the Nazi

conspirators". 28 This was easy to prove, but it was much harder to relate such a vague assessment of the SA's general character to particular crimes punishable by law. Storey distinguished four distinct phases or aspects of the SA's history: apart from his first aspect that described the $\mathrm{SA}^{\prime}$ S role in disseminating the Nazi ideology (1), the remaining three described three chronological phases - the period prior to the Nazis seizure of power (2), then its role in the first years of Nazi rule (3), and finally a period or aspect that designated the $\mathrm{SA}^{\prime} \mathrm{S}$ "employment as an agency for the building up of an armed force in Germany in violation of the Treaty of Versailles and for the preparation of the youth of Germany - mentally and physically - for the waging of an aggressive war" (4). 29 It is this latter phase (or rather aspect) that is most interesting here, as the previous periods Ibid. 
of the SA's history are well known and the prosecution by and large drew an accurate picture on them that still stands today. From the legal perspective of 1945/1946, the fourth point was likewise the most important one, as it was above all in reference to this period that the prosecution had to prove that the SA had indeed provided the framework in which their members had committed "crimes against peace" or were responsible for "war crimes", as defined in the legal terms mentioned before.

Storey claimed that "the SA developed from scattered bands of street ruffians to a well-knit, cohesive unit organized on a military basis with military training and military functions and, above all, with an aggressive, militaristic, and warlike spirit and philosophy" in the years between 1934 and 1939.30 Every year from 1934 onwards, he added, up to 25.000 officers and non-commissioned officers were militarily trained in the 25 SA troop schools and in the three SA Reichsführer schools. ${ }^{31}$ However, Storey also admitted somewhat contradictory that the $\mathrm{SA}$ "started a rapid decline in its importance" after the murder of Röhm. ${ }^{32}$ Regardless of such

30 Ibid., 125.

31 Statement of Robert G. Storey on 19.12.1945, in: ibid., 151.

32 Ibid., 138. 
inconsistencies, Storey's accusations regarding the late SA appear well grounded. Pointing to the $\mathrm{SA}^{\prime} \mathrm{S}$ role in the Anschluss of Austria and in the occupation of the Sudetenland, Storey claimed that this alone would prove that the SA "had been used as a striking force in the first steps of the aggressive war". 33 In both cases, he argued, did the SA not only provide logistical help, but also provided thousands of fighters, both as the "backbone" of the Sudeten German Free Corps and also in the "Austrian legion", an SA brigade consisting of Austrian refugees in the Reich and formed as early as $1933 .^{34}$ He also pointed to the last stages of the war, from 1944 onwards, when, according to the testimony of the SS-Brigadeführer Walter Schellenberg, 35 the SA took over

33 Soviet Chief Prosecutor Roman Rudenko made a similar point on 2.3.1946, see ibid., vol. 8, 473.

34 On the relationship between the SA and the sudeten German Free Corps see S. Dölling, "Grenzüberschreitende Gewalttätigkeit - die SA und die 'Sudetenkrise'", in: Müller / Zilkenat, Bürgerkriegsarmee, 241-263. On the Austrian Legion, see H. Schafranek, Söldner für den Anschluss: Die Österreichische Legion 1933-1938, Wien 2010. 35 On Schellenberg see R. R. Doerries, Hitler's Last Chief of Foreign Intelligence: Allied Interrogations of Walter Schellenberg, London, New York, 2007. 
several "functions which had previously been entrusted only to the SS, the Sipo [Sicherheitspolizei, DS], and Army": the guarding of concentration camps and of prisoner-of-war camps as well as the supervision of forced labourers in Germany and in occupied areas. ${ }^{36}$ All this would prove, so Storey concluded, that the SA as an organisation as well as their individual members "were in fact co-conspirators and participants in a conspiracy which contemplated and involved Crimes against the Peace and Crimes against Humanity and War Crimes." 37

\section{Honourable Men in a Futile Organisation: The Strategies of the Defence Team}

The defence naturally challenged such far-reaching accusations. The $\mathrm{SA}^{\prime} \mathrm{S}$ defence team in Nuremberg consisted of three parties: the lawyer Georg Boehm and his team as well as the two chosen barristers Dr Martin Löffler and Dr Theodor Klefisch. 38 The personal papers of the latter, since the late

36 Statement of Robert G. Storey on 19.12.1945 in: Trial of the Major War Criminals, vol. 4, 158.

37 Ibid., 159.

38 H. Seliger, Politische Anwälte? Die Verteidiger der Nürnberger Prozesse, Baden-Baden 2016, 191-193. 
Weimar years a respectable although only regionally known criminal defence lawyer from Cologne, have been made available for historical research only recently. 39 They contain among other things documents that deal with Klefisch's role as a lawyer at the IMT and allow for a relatively detailed analysis

Martin Löffler (1905-1987) received his Ph.D. in law from Eberhard Karls University, Tübingen, in 1928. Between 1927 and 1933, he was a member of the German People's Party (DVP). He later joined the Reiter-SA. During World War II, Löffler served in the Wehrmacht before he became a military judge in 1944. After the Third Reich, he rose to the position of one of the leading authorities in the field of press law in the Federal Republic. For a short biographical sketch, see his entry in the Munzinger archive and the information provided on the homepage of the solicitor's office he had founded after the war: http://www.rae-loeffler.de/geschichte.php [last accessed 12.4.2016]. At the IMT, Klefisch in the first place acted as lawyer for Gustav Krupp von Bohlen und Halbach. The biography of Georg Boehm (1900-1952), a Nuremberg based lawyer since 1929, is virtually unknown.

39 So far we lack a biographical study of Th. Klefisch. On his reputation in Weimar Germany see I. Lachmann, "Die Größen der Berliner Advocatur", in: Das Kriminal-Magazin 3 (1931) 29, digitised: http://www.anwaltsgeschichte.de/kriminalmagazin/kriminal-magazin.html [last accessed 13.7.2015] . 
of the strategy applied by the defence team. As Klefisch never spoke in court and only deposited a "speech in writing" on 15 August 1946,40 we can assume that he mostly did background work for his colleagues. Amongst other things, Klefisch is said to have provided a detailed memorandum on the SA. 41 Klefisch's work concentrated on those SA men that had formerly been members of the "Stahlhelm. Bund der Frontsoldaten" (literally: Steel Helmet, League of Frontline Soldiers), a paramilitary veteran's organisation that had close ties to the conservative DNVP until it was gradually dissolved and its members for the most parts integrated into the SA between 1933 and 1935.42 The relationship between these two organisations

40 See the statement of Geoffrey Lawrence on 15.8.1946, in: Trial of the Major War Criminals, vol. 21, 175. Klefisch not speaking in court was partly the result of tensions among the laywers defending the SA, see Seliger, Politische Anwälte?, $192-193$

41 Statement by Löffler on 30.8.1946, in: ibid., vol. 22, 333. The memorandum in question is not included in Klefisch's files. It is possible that the memorandum in question is in fact the one written by Jüttner, as quoted above. 42 V. R. Berghahn, Der Stahlhelm: Bund der Frontsoldaten 1918-1935, Düsseldorf 1966, 245-274; A. Hoffstadt, "Eine Frage der Ehre - zur 'Beziehungsgeschichte' von "Stahlhelm. Bund der 
had been strained before 1933, not least because of class and generational differences - in simplified terms: the SA appealed to young men, the stahlhelm to their fathers 43 - and remained complicated in the years to follow. In the final plea of the SA defence lawyers, delivered on 28 August, Georg Boehm emphasised this alienation. Referring to the various testimonies and affidavits provided, he stressed (alleged) strong ideological differences between NSDAP and the Stahlhelm and concluded: "A large number of the members of the Stahlhelm represented a body within the SA, united by common ideals, who regarded the events of the time with the greatest distrust."44 The overall strategy of the defence team was to use the complexities of the $\mathrm{SA}^{\prime} \mathrm{s}$ internal structure and the fact that its form had changed considerably at least two times between 1921 and 1945 to their own advantage, arguing that it would be highly unfair and legally unsound to declare such a massive

Frontsoldaten' und SA", in: Müller / Zilkenat, Bürgerkriegsarmee, 267-296.

43 For details see Hoffstadt, "Stahlhelm und SA", 270-277. 44 Statement of Georg Boehm on 28.8.1946, in: Trial of the Major War Criminals, vol. 22, 157. 
organisation with its up to 4.5 million of former members 45 as outright "criminal". Martin Löffler for the defence team pointed out that this would be the more incomprehensible as, according to the denazification laws applicable in the American Zone of Occupation, all SA ranks up to the level of Sturmführer were not regarded as in need for automatic punishment. In fact, at a time when the SA as an organisation was in its entirety accused of having been criminal, some of its former members were just recently and legally elected as community councillors, Löffler claimed. 46

The strategy of the defence team proved successful. Already on 28 February 1946, Sir David Maxwell Fyfe from the British prosecution team asked to exempt all wearers of the SA Sports Badge who were no regular SA members, the SA-controlled home guard units and the SA Reserve from prosecution. 47 Only the main body of the SA should be considered for punishment.

45 This number, at least, was the estimate of Dr Kuboschok, defence lawyer for the former Reichsregierung, expressed at the Nuremberg hearing on 28.2.1946, in: ibid., vol. 8, 392. 46 Statement of Martin Löffler on 1.3.1946, in: ibid., 415. It remained unclear whether this statement was correct, and if so, how many former SA men were actually elected. 47 Statement of Sir David Maxwell Fyfe on 28.2.1946, in: ibid., 370 . 
However, defence lawyer Löffler claimed in the following session on 1 March 1946 that criminal proceedings against the SA still affected everyone "who ever belonged to the SA, even for a very short time, during the 24 years between its establishment in 1921 and its dissolution in 1945, that is to say, during a period of almost a quarter of a century". 48 Not surprisingly, Löffler downplayed the SA'S importance during the war years as best as he could. In a reply to storey's accusation, he stated:

Crimes against the laws or customs of war are not charged to the SA. It is true that the Prosecution presented an affidavit saying that the SA also took part in guarding concentration camps and prisoner-of-war camps and in supervising forced labor; but, according to the presentation of the Prosecution, this did not occur until 1944 within the framework of the total war raging at that time, and it has not been charged that this activity of the SA involved any excesses or ill-treatment. [...] The few offenses against humanity charged to the SA by the Prosecution and committed by individual members in the course of almost a quarter of a century can in no way be 
compared with the serious crimes against humanity of which we have heard here. ${ }^{49}$

Löffler went so far as too try to impress the court by presenting figures no one could actually verify. At most 2 per cent of all SA men had participated in punishable individual actions, whereas 98 per cent "kept their hands clean", Löffler stated. He even claimed that this overwhelming majority of all former SA men would strongly deny that they had been called upon to pursue criminal aims or methods by their leaders. 50 Without being explicitly mentioned, the intense public debate about German "collective guilt" provided the background of such reasoning. 51

In case his arguments presented so far, based on a mixture of logic and audacity did not make a favourable impression on the court, the defence team also tried the means of ingratiation. To such ends, Löffler presented the following argument:

\footnotetext{
49 Ibid., 410.

50 Ibid., 411.

51 Cf. the meanwhile "classical" text by K. Jaspers, Die Schuldfrage, Heidelberg 1946. For a detailed analysis of Jasper's text in the context of the early post-war years see Parkinson, An Emotional State, 25-65.
} 
The sober political instinct that is characteristic of the citizens of England and America is non-existent in the Germans. We are a politically immature people, credulous, and consequently especially susceptible to political misguidance. The Court should not overlook this dissimilarity when passing its judgment on the good faith of the individual members of the organizations. According to the impressions which the Defense of the SA has received to date from its visits to camps and from numerous letters, the majority of SA members are convinced that they did not belong to any criminal organization. 52

However, as can be seen in the Klefisch papers today, the defence team did not simply "receive" such apologetic letters, it was also involved in fabricating them. One of the letters addressed at Klefisch is particularly revealing with regard to the "authenticity" of the arguments presented by the lawyers in court: in June 1946, a certain Dr Ludwig Hentschel, an engineer from the city of Münster in Westphalia, confirmed to having received a letter from the lawyer in the previous month. In reaction to this, the engineer told Klefisch that he and his "comrades" had immediately begun to "reformulate and complement" their initial affidavit from 10 May 1946 according

52 Statement of Martin Löffler on 1.3.1946, in: Trial of the Major War Criminals, vol. 8, 412. 
to the lawyer's demands. 53 Such a correspondence makes plain that personal observations of former SA men and their affidavits - in post World War II Germany commonly referred to as "Persilscheine" ("whitewash documents") - do by no means serve as "innocent" autobiographies in a nutshell, but needs to be analysed as deliberate and conscious attempts to reconcile individual biographies with the new political and legal orders. They often served very practical means, be it to increase the writer's change for re-employment or to ward off legal prosecution. As testimonies of the zeitgeist, oscillating between the general acknowledgement of the constraints one had to experience while living in the Third Reich and at the same time serving individual exculpation strategies, they remain an important historical source. They testify to the collective effort in establishing - in the case discussed here - a particular view of the SA, with some revealing wordings. Just to give one example, a Bavarian railway employee wrote tellingly that only very few of the SA men had "actively participated in acts of terrorism". 54 He

53 Letter from Dr. Ludwig Hentschel to Theodor Klefisch from 13.6.1946, in: University and City Library of Cologne, Archives, Zugang 726 (Verteidigerakten Theodor Klefisch), File 2, No. 10 .

54 Affidavit of the railroad employee and former SA man Reiner Pittinger from 7.6.1946, in: University and City 
thus involuntarily confirmed that such acts had taken place and that he knew of it, even if not all stormtroopers had taken part in such actions.

\section{The Verdict and its Interpretations}

The Nuremberg judges delivered their verdict on 30 september 1946. With regard to the SA, its findings divided the history of the SA into two distinct periods, up to the summer of 1934 and afterwards. As for the first period, it was clear that the SA has committed crimes, but these crimes were limited to German soil and did not match the criteria of the tribunal. With regard to the latter period, the verdict is most interesting, as it tried to "reconcile" two contradictory perspectives, that of the prosecution and that of the defence team. "Isolated units of the SA", so the judges ruled, had been "involved in the steps leading up to aggressive war and in the commission of war crimes and crimes against humanity", thus confirming the argument of the prosecution. The court here explicitly referred to the occupation of Austria, the SA's contribution to the Sudeten German Free Corps, but also to transports of prisoners of war and the guarding of prisoners, undertaken by the SA group sudeten and by SA units

\footnotetext{
Library of Cologne, Archives, Zugang 726 (Verteidigerakten Theodor Klefisch), File 3, No. 37.
} 
in Danzig, Poznan, Silesia and the Baltic states. ${ }^{5}$ The judges also mentioned the $\mathrm{SA}^{\prime} \mathrm{s}$ active participation in the Jewish pogrom on the night of the 9 to 10 November 1938, the infamous "Crystal Night" or "Night of Broken Glass", and the "illtreatment" of Jews in the ghettos of Vilna and Kaunas. 56 In a noticeable contrast to such allegations, the court nevertheless agreed with the defence in as much as they adopted the position that "the SA was reduced to the status of a group of unimportant Nazi hangers-on" after the 1934 purge. This finally brought them to a verdict of not guilty: "Although in specific instances some units of the SA were used for the commission of war crimes and crimes against humanity, it cannot be said that its members generally participated in or even knew of the criminal acts. For these reasons the Tribunal does not declare the SA to be a criminal organization within the meaning of Article 9 of the Charter". 57 The same applies, ruled the court, for the Reich Cabinet and the "General Staff and High Command", whereas SS, SD, the Gestapo and certain groups within the NSDAP Leadership Corps were

55 The Verdict of the IMT, pronounced 30.9.1946, in: Trial of the Major War Criminals, vol. 22, 518.

56 The Verdict of the IMT, in: ibid., 519.

57 The Verdict of the IMT, in: Trial of the Major War Criminals, vol. 22, 519. 
found guilty. The journalists present on 30 september 1946 unanimously commented approvingly. For Hans-Achim von Dewitz, writing in the German weekly Die Zeit, the verdict was "objective and thorough". He likewise suggested that it would be "politically wise". 58 However, Dewitz" case urges caution: Prior to 1945, he had made a considerable career as a Nazi journalist and his new political reasoning was probably more due to tactical considerations and practical necessity (the reports of accredited German journalists were subjected to post-censorship) than the result of a genuine political conversion. 59 At least with regard to the acquittal of the SA, it is nevertheless safe to assume that the silent majority of Germans indeed approved the verdict, even if they contested the legitimacy of the court in the first place. 60

58 H.-A. von Dewitz, "Die Tage der Entscheidung. Auf der Tribüne in Nürnberg", Die Zeit, 3.10.1946, 3. 59 M. Urban, "Kollektivschuld durch die Hintertür? Die Wahrnehmung der NMT in der westdeutschen Öffentlichkeit, 19461951", in: Priemel / Stiller, NMT, 684-718, 684-685. About Dewitz' journalistic work in the Third Reich see P. Köpf, Schreiben nach jeder Richtung: Goebbels-Propagandisten in der westdeutschen Nachkriegspresse, Berlin 1995, 157-158. 60 D. Bloxham, "Prosecuting the Past in the Postwar Decade", in: D. Bankier / D. Michman (eds.), Holocaust and Justice: 
Lawyer Klefisch attributed the fact that the Nuremberg judges treated the stormtroopers relatively lenient in large part to his own defence strategy that had painted a portrait of the SA as a highly complex, but ultimately toothless bureaucratic institution in that many Germans had only involuntarily spent a short spell of their lives. ${ }^{61}$ shortly after the verdict, in a letter dated 5 November 1946, he claimed that the specific situation of the integration of the former stahlhelmers had more or less saved the whole SA from punishment: "That the entire SA was not declared a criminal organisation was to a good degree a consequence of the fact that it had incorporated a great deal of people from the stahlhelm within its rank-and-

Representation \& Historiography of the Holocaust in Post-War Trials, Jerusalem, New York 2010, 23-43, 37-39. On the methodological problems in assessing the German reactions to the IMT see H. Krösche, "Abseits der Vergangenheit. Das Interesse der deutschen Nachkriegsöffentlichkeit am Nürnberger Prozess gegen die Hauptkriegsverbrecher 1945/46", in: J. Osterloh / C. Vollnhals (eds.), NS-Prozesse und deutsche Öffentlichkeit: Besatzungszeit, frühe Bundesrepublik und DDR, Göttingen 2011, 93-105.

61 The early research literature on the IMT shared the view that the SA's acquittal was largely the result of a clever defence strategy and the picture of the SA it had painted. See Rauschenbach, Der Nürnberger Prozeß, 90 . 
file. The conduct of the latter had been proven to be without a flaw. It was simply not possible to label an entire organization as outright criminal if it contained such a great number of irreproachable members." 62

Several weeks later, on 16 December 1946, Klefisch furthermore completed a memorandum of thirty pages length. It has survived in the papers of Otto Freiherr von Waldenfels, the Stahlhelm leader for Bavaria in the early 1930s, and was originally designed as an argumentation aid for his clients in potential differences of opinion with Allied authorities. Klefisch here summarised and explained the main results of the IMT with regard to the SA and the Stahlhelm. In his reading, the Stahlhelm was not only a "democratic" organisation, but furthermore one that stood in the "starkest contrast to Nazism". This contrast, he exclaimed, resulted in nothing less than a "fight between death and life". 63 Those active

62 Letter of Theodor Klefisch to an unknown addressee from 5.11.1946, in: University and City Library of Cologne, Archives, Zugang 726 (Verteidigerakten Theodor Klefisch), File 2 .

63

Th. Klefisch, Denkschrift über den Charakter des Stahlhelm, Bund der Frontsoldaten, und seine Einstellung gegenüber dem Nationalsozialismus anhand des dem Internationalen Militär-Gerichtshof vorgelegten Materials, in: 
Stahlhelmers who refused to be integrated in the regular SA after 25 January 1934, Klefisch claimed, in most cases experienced or were at least threatened with arrest. Deemed "politically unreliable", they remained under the surveillance of the Gestapo until the end of the Third Reich, Klefisch maintained. 64 on the other hand, even those stahlhelmers who did not object to the transfer to the SA ultimately did good: because of the high number of irreproachable stahlhelmers that were "retained" in the SA, the influence of the ideological hardliners, the "old fighters and fanatics" within the stormtroopers decreased, Klefisch asserted. 65

The main motive of the lawyer's controversial interpretations becomes clear at the end of this memorandum: The majority of former Stahlhelmers who had been integrated in the SA between 1933 and 1935 occupied, by the end of the Third Reich, SA ranks so important that the laws of the Allied Control Council requested particular scrutiny in the upcoming denazification processes. This would be the case for all ranks of SAScharführer and higher, Klefisch explained. ${ }^{6}$ Not

Bayerisches Hauptstaatsarchiv, Abt. IV, Bestand Stahlhelm, No. $360,5,7$ (of the memorandum).

64 Ibid., 22.

65 Ibid., 3.

66 Ibid., 25. 
surprisingly, the lawyer regarded this classification as highly unfair for his clients. His defence strategy on this point exploited the different leadership principles of the SA and the Stahlhelmers: In contrast to the organisation of the Stahlhelm, in which leadership ranks always indicated active duties, the formal rank of a particular stormtrooper in the SA did not always correspond with actual leaderships tasks carried out but this person, he explained. The SA also knew honorary leaderships position, a so-called "inactive leadership corps", and many of those former stahlhelmers who, after integration in the SA, did not perform leadership tasks, belonged precisely to this second category, Klefisch claimed. Therefore, they should be exempt from the authority's aforementioned particular scrutiny. 67

\section{Spatial and Temporal Limits to the Persecution of SA Crimes}

However self-congratulating and obviously partisan Klefisch's statements were, it is hard to ignore that they influenced the judges at the IMT and that the $\mathrm{SA}^{\prime} \mathrm{S}$ acquittal in Nuremberg set the tone for the next decades, at least in the Federal Republic of Germany. West German courts' convictions of stormtroopers remained limited, with the notable exception of their excessive acts of violence in 1933 and 1934 as well as 
because of the crimes committed at "Crystal Night". 68 The fact that these crimes had often been "public" crimes now backfired; the deep impact of the $\mathrm{SA}^{\prime} \mathrm{s}$ brutality in the wake of the establishment of the Third Reich often allowed for detailed reconstruction of these acts even fifteen to twenty

68 Recently, however, the historian Edith Raim came to a somehow different conclusion. Based on an impressive collection of case studies of post World War II criminal trials against Nazi perpetrators, Raim argues that "surprisingly very many criminal investigations were started" despite the authorities' materially and personally insufficient conditions. The judiciary contributed positively to the "democratisation" of the Federal Republic, a role so far acknowledged only insufficiently, she concludes. Against such a positive assessment, I would emphasise that despite the punishing of individual stormtroopers, the West German judiciary by and large remained blind to the systematic character of the Nazi rituals of violence. Individual wrongdoings were often sentenced as "excess perpetrators" measured, thus, against a highly problematic image of the Third Reich as a state of "law and order". See E. Raim, Justiz zwischen Diktatur und Demokratie: Wiederaufbau und Ahndung von NS-Verbrechen in Westdeutschland 1945-1949, Munich 2013, 748, $1173-1177$. 
years later. ${ }^{69}$ Unsurprisingly, in the Soviet Zone of Occupation, Soviet- and later also East German authorities demonstrated a particularly vivid interest in the prosecution of crimes committed by SA men that had been directed against the members of the Communist and Socialist parties. Everywhere in East European states now under tight Soviet control, the intense suffering of adherents of the political left persecuted by Fascist and extreme nationalist regimes was exploited as a means to silence the quickly rising protests against the new Communist authorities. ${ }^{70}$ In the Soviet Zone of Occupation, the recollection of stormtrooper's violence

69 See above all the aforementioned collection of cases in Raim, Justiz zwischen Diktatur und Demokratie, 659-944, as well as the database Justiz und NS-Verbrechen / Nazi Crimes on Trial. German Trial Judgements concerning National Socialist Homicidal Crimes 1945-2012, collected and compiled by Chr. F. Rüter / D. W. de Mildt, online: http://www1.jur.uva.nl/junsv/. 70 D. Stone, Goodbye to all that? The Story of Europe since 1945, Oxford 2014, 20-22; L. Karsai, "The People's Court and Revolutionary Justice in Hungary, 1945-46", in: I. Deák / J. T. Ross / T. Judt (eds.), The Politics of Retribution in Europe: World War II and its Aftermath, Princeton, NJ 2000, 233-251; B. Abrams, "The Politics of Retribution: The Trial of Jozef Tiso in the Czechoslovak Environment", in: idem, 252289. 
exercised in the early years of Nazi rule - directed overwhelmingly against their political opponents from the political left and the Jews ${ }^{71}$ - now served the purpose of legitimising the new political order. Remarkably, this glorification of Communist's suffering and death shared an important similarity with the Fascist cult of their "martyrs" in previous years: In both cases, the ordeal of "party martyrs" placed the living under the obligation to follow. ${ }^{72}$ Once the GDR was firmly established, however, judicial attempts to punish Nazi crimes decreased dramatically since the early 1950s, showing a remarkable parallel compared with the West German path of Vergangenheitsbewältigung. ${ }^{73}$

71 See, pars pro toto, the contributions to the recent volume by N. Wachsmann / S. Steinbacher (eds.), Die Linke im Visier: Zur Errichtung der Konzentrationslager 1933, Göttingen 2014. 72 For the fabrication of National Socialist "martyrdom" see S. Behrenbeck, Der Kult um die toten Helden: Nationalsozialistische Mythen, Riten und Symbole, Greifswald 1996, in particular 184-193, 333-343. For a case study see D. Siemens, Horst Wessel: Tod und Verklärung eines Nationalsozialisten, Munich 2009, 131-149. 73 See above all the detailed study by A. Weinke, Die Verfolgung von NS-Tätern im geteilten Deutschland. Vergangenheitsbewältigungen 1949-1969, oder: Eine deutsch- 
While some of the $\mathrm{SA}^{\prime} \mathrm{s}$ lower ranks were at least sentenced in post-war Germany, usually to moderate penalties, high-ranking SA generals, if they stood trial at all, overwhelmingly got away with light sentences or were acquitted. Such was the case, for example, of Adolf-Heinz Beckerle, SAObergruppenführer in Hesse and police president in Frankfurt on the Main from 1933 to 1939 and appointed German envoy to Bulgaria in 1941. In this latter role, he had been directly involved in the deportation of approximately 11.000 Jews from Macedonia and Thrace. A first attempt to hold the former police president accountable for his involvement in the persecution of German anti-Nazis during the 1930 s came to nothing, as the Frankfurt prosecution closed the case in 1957. Beckerle ultimately stood trial in his hometown beginning in November 1967, but proceedings against him were closed in the summer of 1968 because of his "ill health". He died a free man in 1976.74 A second example is the afore-mentioned Wilhelm

deutsche Beziehungsgeschichte im Kalten Krieg, Paderborn 2002, 43-49, 63-75; and F. Werkentin's pioneering Politische Strafjustiz in der Ära Ulbricht, Berlin 1995, 168-173. 74 For details on this trial see idem, 258-286; S. Meinl, "Adolf Heinz Beckerle, Frankfurter SA-Führer, Polizeipräsident und Diplomat", http://www.ffmhist.de/ffm3345/portal01/mitte.php?transfer=t_ak_beckerle_01 [last accessed $12.4 .2016]$ 
Schepmann, a teacher by profession and later SAObergruppenführer, who acted as the last SA Chief of Staff between 1943 and 1945, following Viktor Lutze's untimely death in a car accident. A Dortmund jury court sentenced Schepmann on 1 July 1950 to a modest prison term of nine months because of his involvement in the violent Nazi takeover of power in 1933, when Schepmann acted as police president of Dortmund. 75 However, he appealed and was ultimately acquitted in 1954. A court in Lüneburg had successfully "denazified" Schepmann already two years earlier, in 1952. ${ }^{76}$ Finally, in 1956, Schepmann was elected deputy mayor in the city of Gifhorn in Lower Saxony. He died in 1970.

Schepmann is a typical case insofar as the prosecution was interested in him only in his role as former regional SA leader and police president of Dortmund. His responsibility for the entire SA between 1943 and 1945 did not concern the courts. In recent years, however, historians have begun to examine the SA of the post-1934 era more closely. Although much needs still to be done, new studies demonstrate that a

75 See the files in: Landesarchiv NRW, Abt. Westfalen, Staatsanwaltschaft Dortmund, No. 1293-1305, 1542-146; Müller, "Schepmann", 531.

76 Denazification file of Wilhelm Schepmann, in:

Niedersächsisches Landesarchiv, Hauptstaatsarchiv Hannover, Nds. 171, No. 25522. 
new assessment of the SA, in particular for the years 1938 to 1945, is needed. The SA not only actively participated in the dismantling of Czechoslovakia, the Anschluss of Austria and the reintegration of the Memelland into the Reich - as already claimed by the prosecution in Nuremberg. Some SA units also fought actively in the Second World War (best-known in this respect is the SA division "Feldherrnhalle") . Finally, stormtroopers also participated in the notorious Partisanenbekämpfung, the combat of alleged partisans, on the Balkan Peninsula, albeit operating undercover. 77

\section{Conclusion}

The initial question of this article was how legal argumentation and courtroom practices affected the historiography of the Second World War. As I have demonstrated, the handling of the SA crimes in Nuremberg where the judges only glanced over important aspects of the later SA for legal and practical reasons, as there were more important issues and individual defendants at stake - set the

77 On these aspects of the SA see S. Döllig, "Grenzüberschreitende Gewalttätigkeit", in: Müller / Zilkenat, Bürgerkriegsarmee, 241-263; Müller, "Schepmann", 520-531; Schafranek, Söldner für den Anschluss, 351-392; as well as my forthcoming comprehensive history of the SA with Yale University Press [publication expected in 2017]. 
tone for the modes in which the history of the stormtroopers was assessed in the decades to follow. That the SA was not declared a "criminal organization" had indeed not only judicial, but also historiographical consequences: First, it contributed to the fact that the history of the SA remained confined to the Germans lands, the old Reich and Austria, and that its transnational activities during the preparation and in the course of World War II were neglected or passed over in silence altogether. In this respect, one can speak of a reregionalisation of a Nazi organisation, as laid out in the introduction to this volume. Second, the proceedings in Nuremberg and its ultimate assessment of the SA made it easier to downplay the structural aspects of stormtrooper violence in the years to come, despite the fact that the individual SA man's Aktionsmacht, or "power of action", 78 had by now means ended in the summer of 1934. As "little guardians of the people's community" 79 they continued to act as a semi-official moral police of the Nazi state until the spring of 1945. Finally, third, the verdict allowed the vast majority of rankand-file stormtroopers to remain unmolested by first Allied

78 H. Popitz, Phänomene der Macht, Tübingen, 21992, 43-47. 79 F. Werner, "Die kleinen Wächter der 'Volksgemeinschaft' : Denunzianten, Boykotteure und Gewaltakteure aus Schaumburg", in: idem (ed.), Schaumburger Nationalsozialisten: Täter, Komplizen, Profiteure, Bielefeld 2009, 521-583. 
and later German judicial investigations unless they were accused of having committed personally attributable crimes in contrast to the members of the SS who could be held responsible by their membership alone and who were comparatively severely punished. 80

In comparative perspective, this feature of the IMT's verdict resembles the outcome of the Tokyo Trial that likewise focussed nearly exclusively on the political and criminal guilt of key figures in the former Japanese administration and in the military, in particular the members of the last Tojo cabinet. The situation was somehow different in other Asian countries where former Japanese perpetrators of lower ranks were prosecuted in several trials, but this did not have

80 In an excellent article, Jan Erik schulte has recently demonstrated that, contrary to the prosecution's intention, the post-war Nuremberg trials with their unequal assessment of the Nazi terror organisations provided the SS men with strategies to present themselves as "scapegoat[s] of various societal groups and institutions of National Socialist Germany" (J. E. Schulte, "The SS as the 'Alibi of a Nation'? Narrative Continuities from the Nuremberg Trials to the 1960s", in: Priemel / Stiller, Reassessing the Nuremberg Military Tribunals, 134-160, 152). 
strong repercussions in post-war Japan. ${ }^{81}$ Here as well as in Germany, the multitude of crimes committed abroad by both Fascist regimes, in Europe as in Asia, was thus not attributed to the many supporters of the regimes but to a few "criminal" individuals - a perspective, however, that historical scholarship, in particular thanks to the booming field of "perpetrator research" since the 1980s, has meanwhile overcome. 82

81 At present, there is considerable research on these socalled B and C trials and their impact. While it is clear that these trials were highly influential in the countries where they took place as well as for the former colonial powers in the region, their impact on post-war Japanese society remained limited. For an overview of this strand of research, see the conference report by L. Schouten, Review of Rethinking Justice? Decolonization, Cold War, and Asian War Crimes Trials after 1945. H-Soz-u-Kult, H-Net Reviews. January 2015, http://www.h-net.org/reviews/showrev.php?id=43337 [ last accessed 12.4.2016], as well as B. Kushner, Men to Devils, Devils to Men: Japanese War Crimes and Chinese Justice, Cambridge 2015; S. Linton (ed.), Hong Kong's War Crimes Trials, Oxford 2013.

82 Most recently: F. Bajohr, "Täterforschung: Ertrag, Probleme und Perspektiven eines Forschungsansatzes", in: idem 
Certainly: that the SA was not pronounced a "criminal organization" in Nuremberg did not - in theory - prevent individual crimes from being punished in the future. In reality, it turned the jurists' as well as the historians' attention to other institutions, organisations and individuals - and maybe rightly so, given the scope of the Nazi crimes committed by SS and SD, the Einsatzgruppen and the Waffen-SS during the Second World War. ${ }^{83}$ However, more than half a century after the Nuremberg trials, I would suggest that it is ultimately time for historians to emancipate from the framework set by a team of international jurists and to write a new and integrative history of the SA that does not necessarily places it "in historian's hell" (to borrow a

/ A. Löw (eds.), Der Holocaust: Ergebnisse und neue Fragen der Forschung, Frankfurt a. M. 2015, 167-185.

83 In this respect, it should be mentioned that the German Spruchkammern in the following years usually carefully assessed the "personal" guilt even of those defendants who had formerly been members of Nazi organisations declared criminal. See H. Boberach, "Das Nürnberger Urteil gegen verbrecherische Organisationen und die Spruchgerichtsbarkeit der Britischen Zone", in: Zeitschrift für Neuere Rechtsgeschichte 12 (1990), 40-50, 45-49; Conze, "Verbrecherische Organisation", 232-236. 
formulation by Christopher Browning), 84 but that at least comes closer to historical reality. The theoretical and practical limits of the legal concept of Organisationsverbrechen (crimes committed by organisations) are not identical equal with the boundaries of historiographical analysis. Needless to say, new comprehensive histories of the SA, and - for the like - of other Nazi organisations, will still benefit from making ample use of court proceedings and the impressive amount of legal documents available. However, at least with regard to the IMT, historians need to pay more attention to the strategies that were at play at the time when these documents were produced. With regard to the historiography of the SA, the perspective advanced here suggests that the lasting importance of this mass organisation for the history of the Third Reich has not been fully acknowledged so far. It is certain that the postwar legend of the SA as an "unimportant union of beer drinkers"85 cannot stand with its genesis in the courtrooms and the Allied internment camps exposed.

84 Chr. Browning, Remembering Survival: Inside a Nazi SlaveLabor Camp, New York, London 2011 [2010], 2.

85 This was the wording in the affidavit of the former SA man Reiner Pittinger from 7.6.1946, in: University and City Library of Cologne, Archives, Zugang 726 (Verteidigerakten Theodor Klefisch), File 3, No. 37. 
Daniel Siemens

Fakultät für Geschichtswissenschaft, Philosophie und Theologie Universität Bielefeld

Universitätsstr. 25

D-33615 Bielefeld

Email: daniel.siemens@uni-bielefeld.de 